\title{
Partnering In Times of Disruptive Change
}

\author{
Alexander Lennart Schmidt ${ }^{1}$, Neele Petzold ${ }^{2}$ and Christian Junker ${ }^{3}$ \\ ${ }^{1,2,3}$ Münster University of Applied Sciences, Corrensstr. 25, D-48149 Münster, Germany
}

\begin{abstract}
Disruptive change" can be described as quick and fundamental changes in the business environment. If companies fail to adequately address these disruptive changes or remain passive, they are often faced with severe challenges. If however, companies address these changes actively or even proactively, they can outperform their competitors. In theory, disruptive innovations are mostly generated by "entrants", start-ups that develop new, disruptive ideas. However, entrants have been shown tolack resources for the straightforward development and market implementation of their innovations. Established firms in contrast, lack the "disruptive innovation thinking". In order for established firms to be successful in the face of disruptive innovation, today's research suggests to either develop new capabilities in-house, to spin-off a new enterprise or to acquire a startup. All these options stick quite close to established companies which makes it questionable if real disruptive innovations can be born this wayand leave out the option of partnering entirely. This article discusses different types of cooperation as a new way to bear disruptive innovations. The exchange of capabilities in a partnership may lead to more diverse thinking in established companies and may provide resources for start-ups.
\end{abstract}

Keywords: Disruptive change, partnering, cooperation, collaboration, innovation, capability, resource, incumbent, entrant, start-up

\section{Introduction}

We live in a fast changing world. Globalization has increased the pace of change, leading to an intensified competition and more frequent operational disruptions. Companies are overexposed to environmental turbulences and managers see themselves confronted with the question of how to stay competitive[1;2]. "Disruptive change"refers to unanticipated and severe disturbances that threaten to destabilise performance and viability [3]. Disruptive change can take on many faces: it can disrupt competitive dynamics, could come in form of natural disasters or appear as manmade crises[3; 4]. Ifdisruptive change appears on the horizon, managers should assemble their capabilities to react to that change before it negatively affects the mainstream business [4].

A well-known and often applied theory to explain disruptive change, is the theory of "disruptive innovation".In their latest article, Christensen et al. conclude that a universally effective response to the threat of disruptive changehas not yet been given[5]. The trouble incumbents have when confronting disruptive change was reduced to missing capabilities (i.e. traditional processes, dependence on most valued customers and investors). It should however be noted that although the researchers have presented several possibilities (i.e. development of missing capabilities in-house, spin-off or acquisition of independent firm) for incumbent firms to react to disruptive change, they have not yet considered partnerships or the perspective of entrants (i.e. startups).

Due to a fast changing environment, especially in information technology, it appears reasonable for firms to enter into a more flexible arrangement. As a matter of fact, strategic alliances, as one form of partnering[8, p. 35], have seen a growing trend [9]. What is more, start-ups are increasingly enjoying the attention of large businesses, as they try to learn from their entrepreneurial spirit and culture, often by means of cooperation [10]. This conceptual paper sets out to make a first approach to understand how partnering might be able to fill the gap in capabilities to confront disruptive change from the perspectives of incumbents and entrants alike. To answer this question, a literature review will be applied, which will result in recommendations for further research, i.e. research question and a potential set of hypotheses. 


\section{Disruptive change}

Disruptive changes are defined by McCann et al. as "severe surprises and unanticipated shocks that destabilize performance, even threaten ongoing viability." [3, p. 45]. Even though key drivers of disruptive change(i.e. shock, surprise, discontinuity)are supposed to be difficult, if not impossible, to predict, the theory of "disruptive innovation" is one approach to explain and predict how disruptive change occurs and which businesses will grow in times of disruption.

The theory of "disruptive innovation" is proposed predominantly by Christensen and gained surpassing attention both in academia and business circles[11]. According to the theory, disruptive innovation describes the process of a new entrant with fewer resources being able to outperform an established organization. As incumbents tend to focus on their most profitable customers and improve their offerings constantly, other, less profitable segments are overlooked. By addressing these segments with "good enough" products, new entrants gain a foothold in the market. Over time, by constantly improving their business model, the entrant's offeringsare able to meetthe requirements of the mass market.Once the offering is adopted by the mainstream market, disruption has occurred.[5; 6, p. 113, 12]

Compared to sustaining innovations, that improve on already existing performance attributes, valued by mainstream customers, disruptive innovations are inferior on the attributes that mainstream customers value, offer new value propositions at lower prices and enter the market from a niche [13]. Moreover, disruptive innovations are a relative phenomenon. Hence, an idea might be disruptive to one organization while being sustaining to another. Basis for assessment is the business model of the incumbent.

\section{Impact of disruptive change}

\subsection{Opportunities of disruptive change}

The theory of disruptive innovation explains how smaller companies (i.e. start-ups) are able to disrupt established firms in an industry, in an effort to provide more affordable and accessible solutions (cf. 2.). In contrast to sustaining innovations, the entrant is able to gain a foothold in an overshoot market and develop its offerings unaffected by the established firms. As disruptive products are usually simpler, more convenient and cheaper, they allow the participation of customers who were previously not served by the market. Overall, disruptive innovation, in contrast to sustaining innovation, create real growth in an industry [14] and present an opportunity for smaller companies to compete successfully against established companies [7].

\subsection{Threats of disruptive change}

When disruptive innovationsare introduced by entrantsto an industry, managers of highly reputable firms were found to jointly fail to respond to its appearance in a successful manner[4; 6, pp. 112-113; 7]. Although these managers are usually highly capable and sensitive to market changes in their industry's environment, identify the respective disruptive innovation and have the resources to confront them[4], established companies were shown to lack the agility and resilience to confront and react to disruptive innovation [3]. At first, it does appear reasonable for managers to refrain from answering to disruptive change. As a matter of fact, established firms can bring about the disruptive change themselves, as they allow for undershoot markets or overshoot markets to occur, which present a foothold to entrants [5]. Further, the new emerging markets do not appeal to large incumbents, as they do not provide sufficient growth potential and target the low-end, low-profit part of the mainstream market. However, as the disruptive innovation is continuously enhanced along its trajectory of performance improvement, it begins to appeal to the mainstream customers (cf. 2). This movement, from the low-end of the market (or a new market) to the mainstream market, was shown to first erode the incumbent's market share and potentially the entire business[5; 12]. 


\subsection{RPV framework}

In order to answer to the threat of disruptive change or to take advantage of the opportunities of it, managers must assess their firms own strength and weaknesses.According to the theory, theanalysis of resources, processes and values (RPV) inherent to the business is an adequate mean for this assessment.

Resources can be either tangible or intangible. It was found that the access to high-quality resources improves a firm's ability in coping with change. In order to get a holistic idea of a firm's capabilities, one must further assess the processes and the values inherent to a firm. Processes are a "firm's patterns of interaction, coordination, communication and decision-making" [6, p. 187]. They can be formal (i.e. defined and noted down) or informal (i.e. evolving over time through ways of working)[15]. Values are the standards by which employees prioritize their actions with regard to serving customers or following new ideas for products and services. Values can inhibit companies in two ways: how companies define acceptable gross margins and how they evaluate business opportunities. Table I summarizes core elements of the RPVs.[4]

TABLE 1: RPV-framework

\begin{tabular}{ll|ll|l}
\hline \hline \multicolumn{2}{c|}{ Resources } & \multicolumn{2}{c}{ Processes } & \multicolumn{2}{c}{ Values } \\
Tangible & Intangible & Formal & Informal & Proxies \\
\hline - Cash & $\bullet$ Brand & $\bullet$ Customer service & $\begin{array}{l}\bullet \text { Background } \\
\text { processes }\end{array}$ & $\bullet$ Cost structures \\
- Distribution network & $\bullet$ Experience & $\bullet$ Hiring and training & $\bullet$ Budgeting & $\bullet$ Investment decisions \\
- Equipment & $\bullet$ Knowledge & $\bullet$ Logistics & $\bullet$ Cultural processes & $\bullet$ Most important customers \\
- People & $\bullet$ Product design & $\bullet$ Manufacturing & $\bullet$ Habits & $\bullet$ Prioritization in production \\
- Products & $\bullet$ Relationships & $\bullet$ Procurement & $\bullet$ Market research & $\bullet$ Size of firm \\
- Technology & & $\bullet$ Product development & $\bullet$ Planning & $\bullet$ Size of opportunity \\
\hline \hline
\end{tabular}

\subsection{Incumbents and entrants}

Incumbentswere found to have problems when dealing with the emergence of disruptive change. Although they are mostly equipped with very capable people, are experienced, have good market and product knowledge and sound financial resources, they often lack the required processes and values needed to answer successfully to disruptive change[7; 16]. Established companies have developed organizational routines, procedures and habits that were build or evolved to carry out repetitive tasks related to their current business in an efficient way. These processes however are inefficient to solve the problem presented by disruptive change[17; 18]. Further, established companies are obliged to meet the demands of their most important investors and customers. CEO's in these companies are accountable to their shareholders and feel the pressure to meet constant growth targets. Disruptive innovations however, by definition, do not fulfil the incumbents need for growth $44 ; 6$, p. 113; 15].

Entrants (i.e. start-ups) were however found to have a different composition of the RPVs in general. It appears as what they lack in resources they make good in processes and values: Although the technological innovativeness and the founder's personality respectively network might be advantageous[19], in sum, the part of resources tend to be ill-equipped. Predominantly, entrants seem to lack financial resources to scale up the venture $[20 ; 21]$. Poor access to human resources and missing relationships to i.e. customers and suppliers are further shortcomings that were identified byresearch $[20 ; 22 ; 23]$. With regard to processes, entrants are found to use immature routines and lack in specific procedures (i.e. patenting, marketing)[23; 24; 25]. However, this simple organizational structure also allows for a high flexibility, quick decision making and can result in a creative opportunism[19;20]. In consideration of values, the newness of the entrant might cause a too strong, disadvantageous risk culture (due to inexperience) respectively a lack in employee commitment[20]. However, as the founder is central in the setting, entrants may profit from entrepreneurial spirit (i.e. entrepreneurial thinking, need for achievement) which is positively related to a high level of motivation on the side of the entrant[20]. Concluding, one can state that entrants could have the right processes and values in place not only to embrace but also to initiate disruptive change in their business environment[26].

The gap in ability to meet disruptive changemight present an opportunity for both categories of enterprises alike. For the ability to initiate disruptive change or to react successfully to it, a company needs the right 
resources, processes and values (cf. 3.3). From the analysis of incumbents and entrants, it appears as thoughincumbents (i.e. established firms) could generally supply the resources and entrants (i.e. start-ups) the processes and values to form the optimal combination of capabilities required for disruptive innovation.

Christensen and Overdorf suggest three ways for bigger companies to obtain the needed capabilities to deal with disruptive change in one's industry[4]: (1) develop the capabilities in-house, (2) spin-off an independent organization or(3) buy a smaller company. A new and currently less well-researched approachis to establish a partnership (i.e. between incumbents and entrants) $[11 ; 27 ; 28]$ to benefit from each other's capabilities and embrace the perspective of both partners simultaneously.

\section{Partnering in times of disruptive change}

Partnering, synonymously used with the term cooperation, is an essential component of numerous companies' growth or competitive strategies. One may notice a common trend towards strategic partnering, especially for small and medium enterprises [29;30]. A reason for the success story of cooperation is the access to resources via partnerships[31]. Contrary to Christensen, other authors include aspects of processes and values into the definition of resources as well [32; 33, pp. 136-144; 34, p. 199]. The access to these resources in partnerships might also be helpful for companies in the context of disruptive innovation where incumbents and entrants (start-ups) could share them. To engross this thought, it is mandatory to define cooperation first of all and to understand the motivation mechanisms of collaboration in depth.

\subsection{Cooperation forms}

Cooperation means the volunteer collaboration of at least two de jure and economically independent partners [35, p. 53]. This cooperation can be organized in different ways of which the following two are detailed:

- Strategic Alliance

- Joint venture

A strategic alliance is the volunteer conjunction of companies to share and develop products, services or technologies [36]. Partnership and strategic alliances are even defined as congruent whenever strategic alliances focus on the strategic and long term component of cooperation [37].

Joint ventures incorporate legally and economically independent partner companies. This leads to far higher exit barriers to quit the joint relationship. On the other hand, this very close proximity enables partners to better access resources of the copartner[38].

Despite these two cooperation forms there are several further options to establish a partnership, e. g. networks just to mention one of them. Networks are assumed to be an extension of strategic alliances, so this research first of all focuses on the binary relationship as the micro-unit of a network. Whenever companies buy goods and services from others this may rather imply a supplier-partnership than a strategic alliance. Therefore, supplier-customer-relationships are not covered here. However, detached of the concrete cooperation form basic theories explaining the phenomenon of collaboration are broadly valid for all of them.

\subsection{Resources and capabilities as cooperation drivers}

The resource based view claims strategic competitive advantages thanks to the existence and application of critical resources within companies [33, pp. 136-144]. It is also possible to use resources and capabilities jointly in partnerships, e.g. in service networks of producing and service providing companies with their complementary equipment [39]. This combination of resources among partners is crucial for the value added that can be achieved together [40].

As partnerships via the two mentioned manifestations of strategic alliances and joint ventures aim to gain access to resources, the question arises how resources could be defined concretely. Resources are not imitable, rare, valuable and not substitutable [41]. A categorization concentrating on tangible resources may be raw material, human resources and equity [42, p. 39]. As mentioned above processual and value aspects can also be defined as resources. This is the reason for a broader understanding of the term in this article. Furthermore (dynamic) capabilities are necessary to achieve a successful application of the resources [43]. In respect of Christensen's differentiation of resources on the one hand and the only partial coverage of processes and values 
by "resources" on the other hand there is a definition-gap. This leads to the conclusion that capabilities should complement resources in terminology.

\subsection{Transaction costs as cooperation driver}

Coase describes "hybrids" as intermediates between hierarchy (make) and market (buy). A partnership offers a compromise between those two extremes which reduces transaction costs[44, pp. 386-405]. The acquisition of resources and capabilities offers maximum flexibility to an enterprise but goes along with a lack of control and high transaction costs. For a development within the companies one will need a long time whilst full control is given and transaction costs are lower. Cooperation offers a way out of this dilemma, transaction costs are comparably low while flexibility is comparably given [6, pp. $197 \mathrm{ff} . ; 45$, p. 48]. However, monitoring costs arise to prevent a partner's opportunistic behavior and reduce the risk of missing reciprocity [46].

Despite resources, capabilities and transactions costs, additional, but in literature less often discussed aspects such as risk diversification or the formation of market entry barriers for competitors or substitutes may be additional drivers for collaboration as well [29; 47, pp. 184-186]. Those drivers can be addressed in further research. Besides partners' resources and capabilities, the common target defines the ideal partner with whom a company should be successful [48]. This target prioritizes resources and capabilities which are valuable for the cooperation.

\subsection{Partnering is enabling and encountering disruptive innovation}

As mentioned above, it should be checked carefully in every single case if partnerships as intermediate solutions are a promising way to gain lacking resources and capabilities [31]. If that is the case as stated in the cited literature, this leads to the question whether cooperation also might be a strategy in the context of disruptive innovation. The resource based view, transaction cost theory and the literature about dynamic capabilities suggesta motivation to collaborate. As analyzed before, partnerships are an intermediate option between the extremes of a make- or buy-decision to get access to resources and capabilities. This option complements the suggested three strategies in disruptive innovation by Christensen and Overdorf (a-c) [4] with a fourth one (d):
a. Develop the capabilities in-house
c. Acquire a start-up
b. Spin-off an independent organization
d. Cooperate with partners

A partnership could solve the challenge of impossibility to sustainably generate real disruptive innovation internally in the long run. The same is valid for the loss of diversity after an acquisition passed by and the acquired company gets part of an incumbent[6, pp. 198ff.].

\section{Research question and hypotheses}

The theoretical derivation of partnering as an additional strategy in times of disruptive change, leads to the following research question:

Can partnerships as an intermediate compromise between internalization (make) and externalization (buy) solve the dilemma of disruptive innovation, which requires the integration of external resources and capabilities on the one hand but proposes separation to sustainably keep the advantages on the other hand?

A corresponding set of hypotheses could be:

The more an incumbent cooperates with entrants (i.e. start-ups) instead of developing resources and capabilities internally/spinning of enterprises/acquiring them, the more disruptive innovations are born.

An additional question is whether the number of disruptive innovations born correlates positively with the length of the corresponding cooperation. A decreasing innovation output after time elapsed could be as imaginable as an increase. Maybe partners assimilate until a stimulation diversity disappears or they foster a more productive collaboration after they know each other better?Moreover, research in the simple number of disruptive innovations could additionally be complemented by the analysis of innovation quality, impact or profitability etc. 


\section{Further research: cooperation constellations}

Besides the investigation into the proposed hypotheses they could be differentiated by possible partner constellations. The constellation of incumbent and entrant (start-up) in a cooperation is only one possibility to approach disruptive innovation partnerships. Especially start-up networks could be successful in gathering their resources to generate synergies and foster efficiency [49, p. 3]. Next to private enterprises like incumbents and start-ups, there is also science as an additional possible player in disruptive innovation. This leads to four partner combinations while the mix of these basic types may appear in practice as well:

1. Incumbent and entrant (start-up)

3. Incumbent and science

2. Start-up network with two or more entrants (startups)

4. Start-up and science

The original task of science to create innovation via basic research can be interpreted as a continuous input for disruptive innovation. Partnerships between private economy and science could be an alternative or extension to the collaboration of incumbents with entrants.

Even though the presented findings contribute to a further understanding of disruptive change, this paper has its limitations. At first, the groups of incumbents and entrants were each seen as homogenous, which is helpful for a first conceptual proposal. However, it might not mirror business reality.Nevertheless, it seems to make sense to continue research in the field of disruptive change and partnering. The findings might have significant impact on companies' success whenever they are facing or actively pushing disruptive innovation.

\section{References}

[1] McGrath, R. G., \& MacMillan, I. C. (2009). How to rethink your business during uncertainty. MIT Sloan Management Review, 50(3), p. 25. Available: http://sloanreview.mit.edu/article/how-to-rethink-your-business-during-uncertainty/

[2] Alpaslan, M., \&Mitroff, I. (2004). Bounded Morality: The Relationship Between Ethical Orientation and Crisis Management, Before and After 9/11. Current Topics in Management, 6, pp. 13-43.

[3] McCann, J., Selsky, J., \& Lee, J. (2009). Building agility, resilience and performance in turbulent environments. People \& Strategy, 32(3), pp. 44-51.

[4] Christensen, C. M., \&Overdorf, M. (2000). Meeting the Challenge of Disruptive Change. Harvard Business Review, 78(2), pp. 66-77.

[5] Christensen, C. M., Raynor, M. E., \& McDonald, R. (2015). What Is Disruptive Innovation? Harvard Business Review, pp. 44-53.

[6] Christensen, C. M. (2011). The innovator's dilemma: the revolutionary book that will change the way you do business (1. Harper Business paperback). New York, NY: Harper Business.

http://dx.doi.org/10.15358/9783800642816

[7] Gaul, P. (2014). Organizations Lack Planning and Tools to Deal With Disruptive Change. Talent Development, (August 2014), p. 24.

[8] Hagenhoff, S. (2008). Innovationsmanagement für Kooperationen: eine instrumentenorientierte Betrachtung. Göttingen: Univ.-Verl. Göttingen.

[9] Narula, R., \&Hagedoorn, J. (1999). Innovating through strategic alliances: moving towards international partnerships and contractual agreements. Technovation, 19(5), pp. 283-294.

http://dx.doi.org/10.1016/S0166-4972(98)00127-8

[10] KPMG (2015). Why are big businesses looking to start-ups for innovation?. Available: https://www.kpmg.com/AU/en/IssuesAndInsights/ArticlesPublications/Documents/big-business-start-upsinnovation.pdf

[11] Danneels, E. (2004). Disruptive technology reconsidered: A critique and research agenda. Journal of Product Innovation Management, 21(4), pp. 246-258.

http://dx.doi.org/10.1111/j.0737-6782.2004.00076.x

[12] Hwang, J., \& Christensen, C. M. (2008). Disruptive Innovation In Health Care Delivery: A Framework For BusinessModel Innovation. Health Affairs, 27(5), pp. 1329-1335. 
http://dx.doi.org/10.1377/hlthaff.27.5.1329

[13] Govindarajan, V., \& Kopalle, P. K. (2006). The Usefulness of Measuring Disruptiveness of Innovations Ex Post in Making Ex Ante Predictions. Journal of Product Innovation Management, 23(1), pp. 12-18.

http://dx.doi.org/10.1111/j.1540-5885.2005.00176.x

[14] Lambert, C. (2014). Disruptive Genius. Harvard Magazine. Available: http://harvardmagazine.com/2014/07/disruptive-genius

[15] Hüsig, S. \& Soppe, B. (2011). Technologiemanagement - Disruptive Technologie. Available: http://www.innovationsmanagement.de/technologiemanagement/disruptivetechnology.html

[16] Vlaar, P.; De Vries, P. \& Willenborg, M. (2005). Why Incumbents Struggle to Extract Value from New Strategic Options: Case of the European Airline Industry. European Management Journal, 23(2), pp.154-169. http://dx.doi.org/10.1016/j.emj.2005.02.009

[17] Macher, J.T. \& Richman, B.D. (2004). Organisational responses to discontinuous innovation: a case study approach. International Journal of Innovation Management, 8, pp. 87-114.

http://dx.doi.org/10.1142/S1363919604000939

[18] Bergek, A.; Berggren, C.; Magnusson, T. \& Hobday, M. (2013). Technological discontinuities and the challenge for incumbent firms: Destruction, disruption or creative accumulation? Research Policy, 42, pp. 1210-1224. http://dx.doi.org/10.1016/j.respol.2013.02.009

[19] Andersson, M., \& Xiao, J. (2016). Acquisitions of start-ups by incumbent businesses. Research Policy, 45(1), pp. 272290. http://dx.doi.org/10.1016/j.respol.2015.10.002

[20] Hyytinen, A., Pajarinen, M., \& Rouvinen, P. (2015). Does innovativeness reduce startup survival rates? Journal of Business Venturing, 30(4), pp. 564-581. http://dx.doi.org/10.1016/j.jbusvent.2014.10.001

[21] Kotha, R., \& George, G. (2012). Friends, family, or fools: Entrepreneur experience and its implications for equity distribution and resource mobilization. Journal of Business Venturing, 27(5), pp. 525-543.

http://dx.doi.org/10.1016/j.jbusvent.2012.02.001

[22] Hsu, D. H. (2007). Experienced entrepreneurial founders, organizational capital, and venture capital funding. Research Policy, 36(5), pp. 722-741. http://dx.doi.org/10.1016/j.respol.2007.02.022

[23] Steinfield, C., Scupola, A., \&López-Nicolás, C. (2010). Social capital, ICT use and company performance: Findings from the Medicon Valley Biotech Cluster. Technological Forecasting and Social Change, 77(7), pp. 1156-1166. http://dx.doi.org/10.1016/j.techfore.2010.03.004

[24] Doutriaux, J. (1992). Emerging high-tech firms: how durable are their comparative start-up advantages? Journal of Business Venturing, 7(4), pp. 303-322. http://dx.doi.org/10.1016/0883-9026(92)90004-B

[25] Helmers, C., \& Rogers, M. (2011). Does patenting help high-tech start-ups? Research Policy, 40(7), pp. 1016-1027. http://dx.doi.org/10.1016/j.respol.2011.05.003

[26] Rothaermel, F. T. (2001). Incumbent's advantage through exploiting complementary assets via interfirm cooperation. Strategic Management Journal, 22(6-7), pp. 687-699. http://dx.doi.org/10.1002/smj.180

[27] Baaken, T. \&Teczke, J. (2014). Managing Disruptive Change by Partnering. In: Baaken, T.;Teczke, J. (eds.) Managing Disruption and Destabilisation, Cracow, pp. 129-142.

[28] Petzold, N.; Junker, C.; Riemenschneider, F. (2014). The Strategy of Hybrid Value Creation as a possible way to manage Disruptive Change, in: Baaken, T.; Teczke, J. (eds.): Managing Disruption and Destabilisation, Cracow, pp. 235-244.

[29] Kale, P. \& Singh, H. (2009). Managing Strategic Alliances: What Do We Know Now, and Where Do We Go From Here?, Academy of Management 23(3), pp. 45-62.

[30] Ennsfellner, I., Jiménez, P. \& Krenn-Neuwirth, E. (2012). Das Geheimnis erfolgreicher Unternehmensnetzwerke Erfolgs- und Hemmfaktoren für kleine Unternehmen, Zeitschrift Führung und Organisation 81(6), pp. 410-415. 
[31] Capron, L. \& Mitchell, W. (2010). Finding the right path, Harvard Business Review 88(7-8), pp. 103-107.

[32] Barney, J. (1991). Firm Resources and Sustained Competitive Advantage, Journal of Management 17(1), pp. 99-120. http://dx.doi.org/10.1177/014920639101700108

[33] Penrose, E. T. (1995). The theory of the growth of the firm, New York: Oxford University Press. http://dx.doi.org/10.1093/0198289774.001.0001

[34] Müller-Stewens, G., \& Lechner, C. (2011). Strategisches Management: Wie strategische Initiativen zum Wandel führen. 4. Stuttgart: Schäffer-Poeschel.

[35] Jacob, M. (2012). Informationsorientiertes Management - Ein Überblick für Studierende und Praktiker, Wiesbaden: Springer Gabler.

[36] Gulati, R. (1998). Alliances and networks, Strategic Management Journal19(1), pp. 293-317. http://dx.doi.org/10.1002/(SICI)1097-0266(199804)19:4<293::AID-SMJ982>3.0.CO;2-M

[37] Das, T. K. \& Teng, B. S. (2003). Partner analysis and alliance performance, Scandinavian Journal of Management 19(1), pp. 279-308. http://dx.doi.org/10.1016/S0956-5221(03)00003-4

[38] Teng, B. S. \& Das, T. K. (2008). Governance Structure Choice in Strategic Alliances - The roles of alliance objectives, alliance management experience, and international partners, Management Decision 46(5), pp. 725-742. http://dx.doi.org/10.1108/00251740810873482

[39] Becker, J., Beverungen, D, Knackstedt, R., Matzner, M, Müller, O. \& Pöppelbuß, J. (2013). Bridging the Gap Between Manufacturing and Service Through IT-Based Boundary Objects, IEEE Transactions on Engineering Management 60(3), pp. 1-15. http://dx.doi.org/10.1109/TEM.2012.2214770

[40] Dong, S., Xu, S. X., \& Zhu, K. X. (2009). Research Note - Information Technology in Supply Chains: The Value of ITEnabled Resources Under Competition, Information Systems Research 20(1), S. 18-32. http://dx.doi.org/10.1287/isre.1080.0195

[41] Newbert, S. L. (2007). Empirical Research on the Resource-Based View of the Firm: an Assessment and Suggestions for Future Research, Strategic Management Journal28(1), pp. 121-146. http://dx.doi.org/10.1002/smj.573

[42] Osterwalder, A. \&Pigneur, Y. (2010). Business Model Generation, New Jersey, NJ: John Wiley \& Sons Inc.

[43] Rotermund, U. \& Kurzhals, K. (2014). Innovationskraft durch Dynamic Capabilities und Vertrauenskultur, in Insurance and Innovation, Eckstein, A., Liebetrau, A. and Seidel, M. (eds.), Karlsruhe, pp. 1-10.

[44] Coase, R. H. (1937). The nature of the firm, Economica4(16), S. 386-405.

[45] Williamson, O. E. (1990). Die ökonomischen Institutionen des Kapitalismus - Unternehmen, Märkte, Kooperationen, Tübingen: Mohr.

[46] Oxley, J. E. \& Sampson, R. C. (2004). The scope and governance of international R\&D alliances, Strategic Management Journal 25(1), pp. 723-749. http://dx.doi.org/10.1002/smj.391

[47] Schneider, J., Minnig, C. \& Freiburghaus, M. 2007. Strategische Führung von Nonprofit-Organisationen, Bern: Haupt.

[48] Shah, R. H. \&Swaminathan, V. (2008). Factors Influencing Partner Selection in Strategic Alliances: The Moderating Role of Alliance Context, Strategic Management Journal29(1), pp. 471-494. http://dx.doi.org/10.1002/smj.656

[49] Wojda, F., Herfort, I. \& Barth, A. (2006). Ansatz zur ganzheitlichen Gestaltung von Kooperationen und Kooperationsnetzwerken und die Bedeutung sozialer und personeller Einflüsse, in Innovative Kooperationsnetzwerke, F. Wojda and A. Barth (eds.), Wiesbaden, pp. 1-26. http://dx.doi.org/10.1007/978-3-8350-9307-2_1 